\title{
Diurnal variations in nitrate content of red beets
}

\author{
HEIKKI KALLIO ${ }^{1}$, RAILA ROUSKU ${ }^{1}$, AARNE SALMINEN ${ }^{2}$ \\ and ELISA TIKANMÄKI ${ }^{2}$
}

I Department of Chemistry and Biochemistry, Laboratory of Food Chemistry, University of Turku, SF-20500 TURKU, Finland

2 Saarioinen Ltd., SF-36420 SAHALAHTI, Finland

\begin{abstract}
The diurnal variations in nitrate content of red beet (Beta vulgaris L. var. conditiva) roots and leaves were observed in cultivations with either no nitrogen fertilizer or with $\mathrm{Ca}\left(\mathrm{NO}_{3}\right)_{2}$ addition. With less nitrate in the soil the diurnal reduction of nitrate content in the afternoon was greater; on the average $55 \%$ in the leaves and $20 \%$ in the roots of the maximum values in the middle of August. With nitrogen fertilizing (100 kg of nitrogen/ha) the corresponding values were about 15 to $20 \%$. The amplitude of alteration decreased toward the end of the growing season, as the nitrate content in the leaves in particular was reduced. In our experimental conditions nitrapyrin, a nitrification inhibitor, had no effect on the nitrate content in roots or leaves.
\end{abstract}

\section{Introduction}

In recent years, special interest has been directed to the cultivation conditions of nitrate accumulating plants. The incentive has been the renewed legislation and recommendations issued in many countries. The nitrate content of red beets can be affected with fertilizers, irrigation and nitrification inhibitors.

Nitrogen fertilizers increase the content of total nitrogen (SHANNON et al. 1967, CANTLIFFE 1973, PECK et al. 1974), amino acids (LeE 1973), protein (Splittstoesser and VANDERMARK 1974), and nitrate (LEE et al. 1971, Cantliffe 1972, Peck et al. 1974; Kallio et al. 1980) in beets. Nitrate in the plant is in dynamic anabolic circulation. Rapid changes in the nitrate balance in beets are controlled through nitrate reductase (E.C. 1.6.6.1.). Activity of the enzyme depends on the type and age of tissue; it is the highest in young leaves (PECK et al. 1974). Conversely, in root the low activity increases toward maturation (PECK et al. 1974). Increasing intensity of light activates the reduction of nitrate in beets (CANTLIFfe 1972, 1973, Minotti and StANKEy 1973).

Loss of nitrate-nitrogen in soil has been estimated to be usually very high, 20 to $80 \%$ (Goring 1964, Prasad et al. 1971), depending markedly, however, on the type and history of the soil (JAAKKOLA 1982, 1984). Con- 
version of different nitrogen sources to nitrate in soil and at the same time acceleration of the loss of nitrogen fertilizers has been retarded by using nitrification inhibitors. The most common and effective is nitrapyrin (2-chloro-6-(trichloromethyl) pyridine) (GoRING 1962 a, b). It inhibits nitrification of ammonium nitrogen and nitrification of fertilizers producing ammonium nitrogen in soil (Goring 1962 a, Turner et al. 1962, Bundy and BREMNER 1974).

Nitrapyrin has been seen to reduce nitrate content in radish (Mills et al. 1976), spinach (Bengtsson 1968, von Kick and Massen 1973, von Siegel and Vogt 1975, Mills et al. 1976), and red beet roots (Kallio et al. 1980). In the case of red beet the reduction has been observed while using urea as the sole nitrogen source (KALlio et al. 1980).

This paper is a report on the diurnal variation in the nitrate content of red beet roots and leaves in field conditions. Beets fertilized with $\mathrm{Ca}\left(\mathrm{NO}_{3}\right)_{2}$ on the one hand and with no nitrogen fertilizer on the other hand were investigated in the middle of August and at the end of September. Effect of nitrapyrin is also reported.

\section{Material and methods}

The object of the study was the globe red beet, Beta vulgaris L. var. conditiva of a commercial variety Rubia Sv. The field experiment was carried out at the Sahalahti Experimental Farm of Saarioinen Ltd. $\left(61^{\circ} 28^{\prime} \mathrm{N}\right.$, $\left.24^{\circ} 20^{\prime} \mathrm{E}\right)$ during the 1978 growing season. As a basal dressing to the analysed medium heavy sandy silt (6-12\% OM), potassium chloride, superphosphate, ammonium molybdate, boron and manganese sulphate (330, $1000,0.5,10$, and $10 \mathrm{~kg} \mathrm{ha}^{-1}$, respectively) were distributed and incorporated into the soil.

The number of treatments was four, with four replicates each. Area of a plot was $30 \mathrm{~m}^{2}$ (randomized plot design). The trial units were: $(1)=$ no nitrogen fertilizer nor nitrapyrin; $(2)=$ no nitrogen fertilizer with nitrapyrin (11 $\left.\mathrm{kg} \mathrm{ha}^{-1}\right)$ with limestone as carrier; (3) $=$ nitrogen $100 \mathrm{~kg} \mathrm{ha}^{-1}$ in form of $\mathrm{Ca}\left(\mathrm{NO}_{3}\right)_{2}\left(14.1 \%\right.$ of $\mathrm{NO}_{3}-\mathrm{N}, 1.4 \%$ of $\mathrm{NH}_{4}-\mathrm{N}$ ) without nitrapyrin; and (4) = same as (3) supplemented with nitrapyrin $(8 \mathrm{~kg}$ $\left.\mathrm{ha}^{-1}\right)$. The fertilizers were incorporated into the soil at a depth of about $13 \mathrm{~cm}$ in rows $17.5 \mathrm{~cm}$ apart. The seeds were planted on June 6 th in rows $\left(63\right.$ seeds $\left.\mathrm{m}^{-1}\right)$ in the middle of the fertilizer rows. Normal farming practice was carried out.

Beets in all the plots were studied four times, twice in the latter half of August and twice at the end of September or in the beginning of October. The replicates of each trial unit were always analyzed parallelly. Five medium-sized plants were taken for a sample from each plot every three hours from 0500 to 1700 hours.

To observe the diurnal variation in individual roots twenty red beets were marked in two of the replicates of all four trial units. A 3-mm diameter sample was bored through each marked beet, avoiding moving of the plant. All twenty wands of one replicate were pooled for the analysis. These analyses were carried out in September to October.

For the nitrate analyses the finely ground samples $(5 \mathrm{~g})$ were shaken for $15 \mathrm{~min}$ with boiling distilled water, and the nitrate in the extract was determined potentiometrically using a nitrate selective electrode (Orion Ltd, Helsinki, Finland). Each analysis was made in duplicate.

\section{Results and discussion}

The variation of nitrate content in beets in August is seen in Figure 1. Both the uptake and reduction of nitrate are induced by light (CAntliffe 1972, 1973, Minotti and Stankey 1973). The induction of uptake was fastest and the net accumulation was the highest in the morning. This indicates that the nitrate permease system and the nitrate reductase can be separate enzymes. According to Figure 1 it is possible that the metabolizable nitrate may act as inductor. The delay between the 

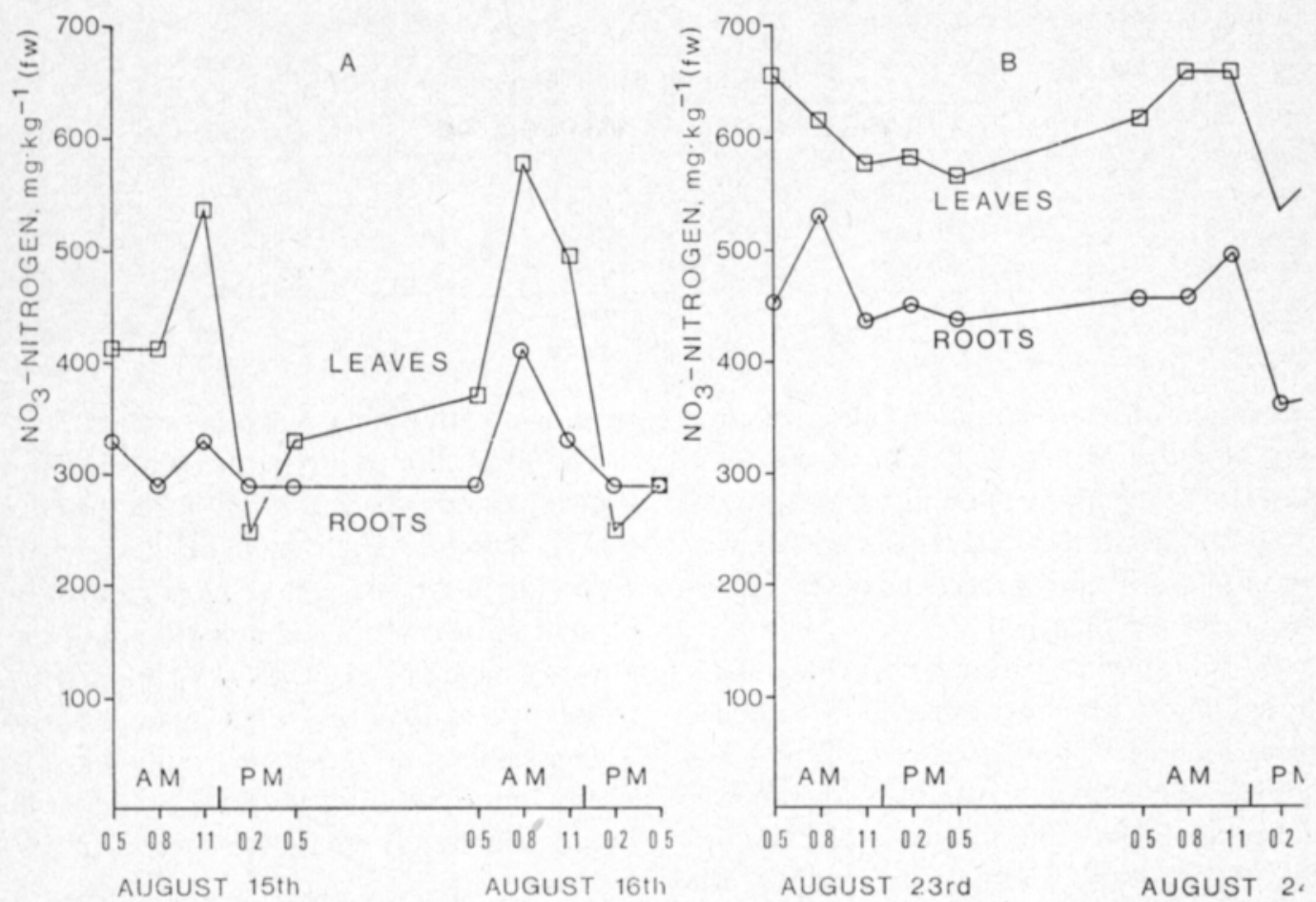

Fig. 1. Diurnal variations of nitrate content in red beet leaves and roots. (A) with no nitrogen fertilizers, (B) with $\mathrm{Ca}\left(\mathrm{NO}_{3}\right)_{2}$ fertilizer (100 kg of nitrogen/ha). Each curve is a mean of eight replicates.
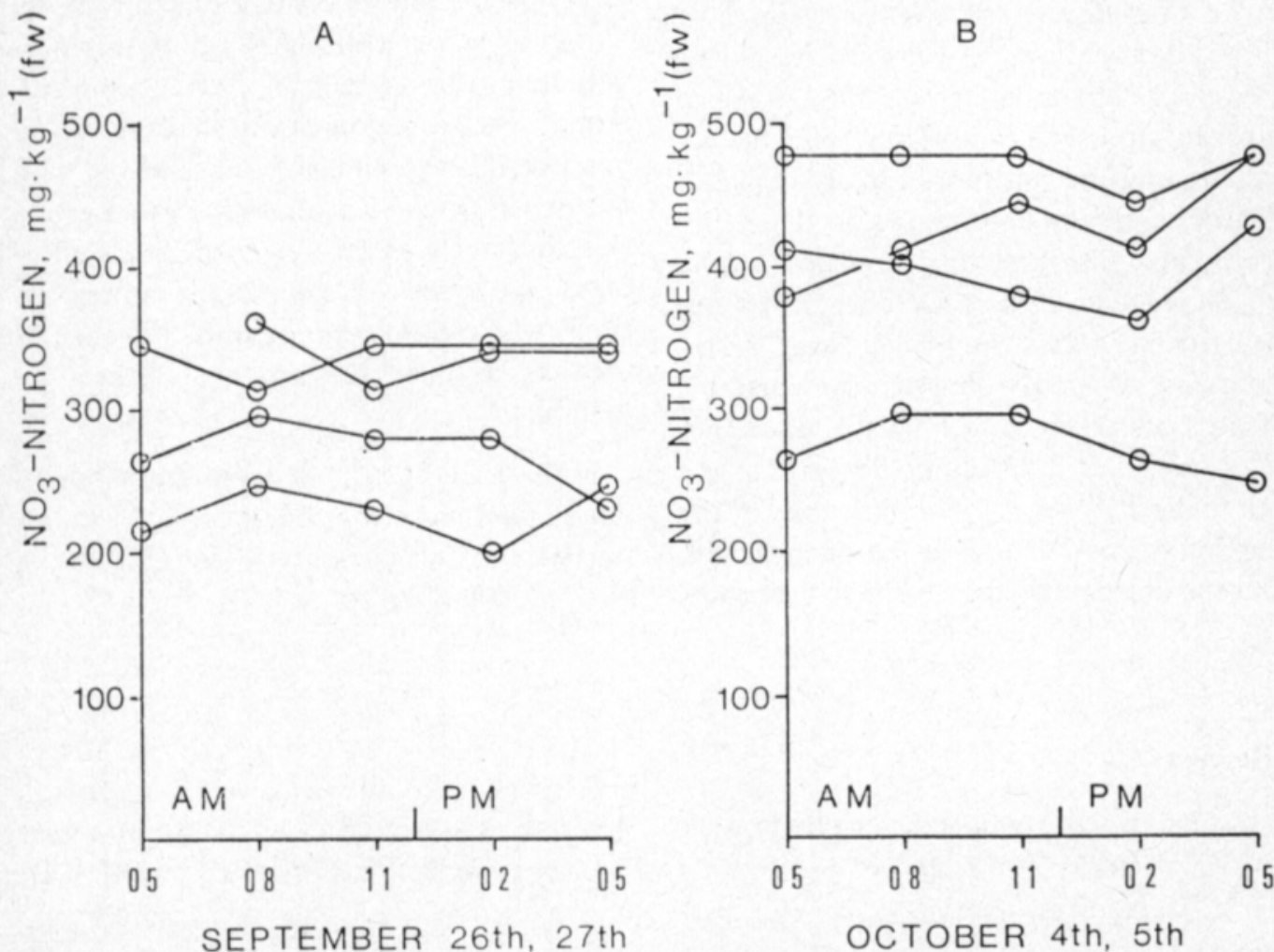

Fig. 2. Diurnal variation in nitrate content of red beet roots analyzed by biopsies in late fall. (A) with no nitrogen fertilizer, (B) with $\mathrm{Ca}\left(\mathrm{NO}_{3}\right)_{2}$ fertilizer (100 kg of nitrogen/ha). Each curve represents one replicate. 
Table 1. Content of nitrate in red beets.

\begin{tabular}{lllllr}
\hline & \multicolumn{3}{c}{ Content of nitrate, $\mathrm{NO}_{3}-\mathrm{N} \mathrm{mg} \cdot \mathrm{kg}^{-1}, \mathrm{f} . \mathrm{w} .(\mathrm{n})$} \\
\cline { 2 - 3 } \cline { 5 - 6 } & \multicolumn{2}{c}{ No nitrogen fertilizer } & & \multicolumn{2}{c}{$\mathrm{Ca}\left(\mathrm{NO}_{3}\right)_{2}$ fertilizer } \\
\cline { 2 - 3 } \cline { 5 - 6 } & Aug 15 to 16 & & & Aug 23 to 24 & Oct 4 to 5 \\
\hline Leaves & $400 \pm 230(40)$ & $270 \pm 140(24)$ & & $610 \pm 180(40)$ & $460 \pm 160(23)$ \\
Roots & $320 \pm 140(40)$ & $300 \pm 80(49)$ & & $440 \pm 160(40)$ & $420 \pm 120(40)$ \\
\hline
\end{tabular}

activation of assimilation and the reduction was about three hours. The BUTZ and JACK. SON (1977) membrane-bound tetrametric enzyme model would not explain the diurnal variation of nitrate in beets or other nitrateaccumulating plants.

In the leaves the diurnal reduction of nitrate content often exceeded $50 \%$ in about three hours in the afternoon. The roots showed an analogous pattern, but with lower amplitude. Thus the nitrate, stored both in leaves and roots, is rapidly liberated for the protein and other syntheses in the afternoon. The effect was clearer when the beets were grown in deficiency of nitrogen (Fig. 1 A) rather than with ample $\mathrm{Ca}\left(\mathrm{NO}_{3}\right)_{2}$ fertilizing (Fig. 1 B). In the latter case the uptake of nitrogen from soil was easier, and the assimilated nitrate was more rapidly replaced. Hence the growth limiting factor, deficiency of available nitrogen, was avoided. Later in fall (September 26th to October 5th) when the beets had almost stopped growing the assimilation of nitrate slowed down and the nitrate peaks such as in Figure 1. could not be observed. Only a minor depression was seen in the afternoon. Non-uniformity of the trial units caused greater deviation in the fall than the diurnal changes in single beet roots as shown with biopsy techniques (Fig. 2).

The total nitrate was reduced during the growing season, especially in the leaves (Table 1). The very high standard deviations, especially in August, of the nitrate nitrogen content are due to the unhomogeneity of the growing medium, plant density, the genetic variation and the cyclic photoperiodical nitrate assimilation. These also explain the difficulty in prediction of the nitrate content in commercial beets even in well controlled cultivations.

It was no surprise that nitrapyrin had no effect on the nitrate content of the red beet leaves or roots with $\mathrm{Ca}\left(\mathrm{NO}_{3}\right)_{2}$ fertilizer or with no nitrogen fertilizing. With urea fertilizer a clear reduction of nitrate both in soil and beets has previously been observed with nitrapyrin (KalLio et al. 1980). Most effective (as much as $50 \%$ ) is the nitrapyrinbased reduction of the nitrate content in beets when ammonium nitrate nitrogen is used as fertilizer (KALLIO and TIKANMÄKI, unpubl.).

In this experiment, nitrapyrin could have a minor positive effect on the crop without nitrogen fertilizing (growth from $27000 \mathrm{~kg}$ $\mathrm{ha}^{-1}$ to $33000 \mathrm{~kg} \mathrm{ha}^{-1}$ ).

\section{References}

BENGTSSON, B.L. 1968. Effect of nitrification inhibitor on yield and nitrate content of spinach. Z. Pfl.ernăhr. Bodenkd. 121: 1-4.

BUNDY, L.G. \& BREMNER, J.M. 1974. Effect of nitrification inhibitors on transformation of urea nitrogen in soils. Soil Biol. Biochem. 6: 369-376.
Butz, R.G. \& JACKsON, W.A. 1977. A mechanism for nitrate transport and reduction. Phytochem. 16: 409-417.

CANTLIFFE, D.J. 1972. Nitrate accumulation in vegetable crops as affected by photoperiod and light duration. J. Amer. Soc. Hort. Sci. 97: 414-418. 
- 1973. Nitrate accumulation in table beets and spinach as affected by nitrogen, phosphorus, and potassium nutrition and light intensity. Agron. J. 65: 563-565.

Goring, C.A.I. 1962 a. Control of nitrification by 2-chloro-6-(trichloromethyl)pyridine. Soil. Sci. 93: 211-218.

$-1962 \mathrm{~b}$. Control of nitrification of ammonium fertilizers and urea by 2-chloro-6-(trichloromethyl)-pyridine. Soil Sci. 93: 431-439.

- 1964. Method and product for treating soil to supress nitrification of ammonium nitrogen therein. U.S. Patent 3.135.594.

JAAKKOLA, A. 1982. Leaching losses in Finnish agriculture. The Second National Symposium on Biological Nitrogen Fixation, Helsinki, 8th-10th of June 1982: 307-313.

- 1984. Miten ravinteet huuhtoutuvat. Leipä leveämmäksi. 4: 6-7.

Kallio, H., Linko, R.R., Tikanmākı, E. \& Puntari, I. 1980. Effect of nitrapyrin on nitrapyrin residues and nitrate content in red beet roots fertilised with urea. $\mathbf{J}$. Sci. Food Agric. 31: 701-708.

Kallio, H. \& Tikanmãkı, E. 1980. Unpubl.

KıcK, H. von \& MAssen, G.G. 1973. Der Einfluss von Dicyanamid und $\mathrm{N}$-serve in Verbindung mit Ammoniumsulfat als $\mathrm{N}$-dunger auf die Nitrat und Oxalsäure von Spinat (Spinacia oleracea). Z. Pfl.ernăhr. Bodenkd. 135: 220-226.

Lee, C.Y., Shallenberger, R.S., Downing, D.L., StoewSAND, G.S. \& PECK, N.H. 1971. Nitrate and nitrite nitrogen in fresh, stored and processed table beets and spinach from different levels of field nitrogen fertilisation. J. Sci. Food Agric. 22: 90-92.
LEE, C.Y. 1973. The effect of nitrogen fertilisation on the total amino acid content of table beet roots. J. Sci. Food Agric. 24: 843-845.

Mills, H.A., Barker, A.V. \& Maynard, D.N. 1976. Nitrate accumulation in radish as affected by nitrapyrin. Agron. J. 68: 13-17.

Minotti, P.L. \& Stankey, D.L. 1973. Diurnal variation in the nitrate concentration of beets. Hort. Sci. 8: 33-34.

Peck, N.H., Cantliffe, D.J., Shallenberger, R.S. \& BourKe, J.B. 1974. Table beet (Beta vulgaris L.) and nitrogen, Search Agric. 4: 1-25.

Prasad, R., Rajale, G.B. \& Lakhdive, B. 1971. Nitrification retarders and slow-release nitrogen fertilizers. Advan. Agron. 23: 337-383.

Shannon, S., Becker, R.F. \& Bourne, M.C. 1967. The effects of nitrogen fertilization on yield, composition, and quality of table beets. Proc. Amer. Soc. Hort. Sci. 90: 201-208.

Siegel, O. von \& Vogt, G. 1975. Über den Einfluss eines Nitrifikationsinhibitors auf die Stickstoffverbindungen des Spinats. Landwirtsch. Forsch. 28: 242-248.

Splittstoesser, W.E. \& Vandermark, J.S. 1974. Nitrates in vegetables: can they be a hazard. Illinois Res. 16: $16-17$.

Turner, G.O., WARren, L.E. \& Andriessen, F.G. 1962. Effect of 2-chloro-6-(trichloromethyl)pyridine on the nitrification of ammonium fertilizers in fiel soils. Soil Sci. 94: 270-273.

Ms received August 13, 1984

\title{
SELOSTUS
}

\section{Punajuuren nitraattipitoisuuden vuorokausivaihtelu}

\author{
Heikki Kallio' $^{1}$, Raila Rousku ${ }^{1}$, \\ Aarne Salminen ${ }^{2}$ ja Elisa Tikanmäki ${ }^{2}$
I Kemian ja biokemian laitos/Elintarvikekemian laboratorio, Turun yliopisto, 20500 Turku
2 Saarioinen Oy, 36420 Sahalahti

Tyőssă tutkittiin punajuuren (Beta vulgaris L. var. conditiva) lehtien ja juuren nitraattipitoisuuden muutoksia vuorokauden eri aikoina. Viljely suoritettiin typpilisällă (100 kg salpietarina) tai ilman. Alhaisella typpitasolla elokuun puolivälissä nitraatin vähenemä oli voimakkainta iltapăivăllă; lehdissă keskimäărin $55 \%$ ja juuressa $20 \%$. Typpilannoitetta kăytettäessă vastaavat văhenemăt olivat pienemmät. Muutosten vuorokautinen amplitudi aleni kasvukauden loppua kohti, jolloin kasvien kokonaisnitraattisisältökin aleni. Juurinăytteiden otossa käytettiin biopsiatekniikkaa. 